\title{
LANGUAGE, EDUCATION AND TRANSNATIONALISM: AN INTRODUCTION
}

\section{LINGUAGEM, EDUCAÇÃO E TRANSNACIONALISMO: UMA INTRODUÇÃO}

\section{Joel Windle* Sarah O'Brien**}

This special issue of Papers in Applied Linguistics brings together eight articles and an interview that provide a wide range of perspectives on the topic of transnationalism. Much research in applied linguistics highlights the growing importance of globalisation and transnational mobility, but often takes these processes and their effects to be self-evident and self-explanatory (BRIGGS, MCCORMICK \& WAY, 2008). As such, this special issue addresses the ways in which transnational movements of populations, linguistic practices, ideology, knowledge and capital shape educational policies and practices related to language. It is concerned with migration, internationalisation of educational provision, student mobility, and global communications.

The present text and the majority of the articles that follow are in English, yet each author is inevitably engaged in transidiomatic practices (JACQUEMET, 2005) through work that engages with variations, and mixes of, Spanish, Portuguese, French, and Haitian Creole, amongst other linguistic forms. The authors also share a commitment to critical scholarship that promotes democratic schooling and society, questioning the commodification of education and reproduction of oppressive social relations by highlighting issues of power and ideology, including those involved in the geopolitics of north-south relations.

Below, we provide some context on the two interrelated types of circulation that will be addressed in the subsequent papers: that of heterogeneous linguistic formations and that of culturally diverse populations. As guest editors, we write from, and into, contrasting locations within these global movements. Brazil is a country with small contemporary migratory movements, but a long and brutal

\footnotetext{
* Universidade Federal Fluminense (UFF), Rio de Janeiro, RJ, Brasil. jawindle@gmail.com

** Trinity College Dublin, Ireland. sarah.obrien@ $@$ tcd.ie
} 
history of transnationalism as the largest destination of the trans-Atlantic slave trade, as well as mass European migration in the $20^{\text {th }}$ century. Ireland, where Sarah is located, by contrast, has been a country of emigration since the $18^{\text {th }}$ century and the Irish diaspora dwarfs the current-day population of Ireland. Currentday Ireland, however, attracts large numbers of international students, including Brazilians, many seeking to learn English. A similar movement can be observed in Australia, a "boutique" destination for Brazilians seeking an international experience and beyond the familiar destinations of North American and Europe (WINDLE \& NOGUEIRA, 2015). While Australia is often taken as a paradigmatic case of a migrant society, outward migration from this wealthy peripheral nation to poor peripheral nations (to use Connell's (2007) distinction), particularly those where English is not widely used, is rare (Joel's transnational trajectory).

\section{TRANSNATIONAL POPULATION FLOWS}

In 2018, global migration indicators estimated a total of 258 million international migrants (UN DESA 2018, UNHCR 2018, ILO 2013, UNESCO 2017). This unprecedented figure encompasses a population of 36.1 million children and 4.8 million international students -more than double the student number recorded in 2000 (IOM UN Migration, 2018). The former are too often denied the educational resources of their new places of settlement (CARDARELLI, 2018). The latter, most often tertiary students from the global south, frequently migrate with the specific intention of purchasing commodified forms of higher education.

Transnational population flows are not new, and despite their treatment in international media as a malign force, are not indicative of a rupture in the human psyche. Since the beginning of time, human populations have followed resources to ensure their survival. What is novel, even unnatural, about migration trends today is the extent to which it is demarcated by global capitalism, and its attendant tributaries of wealth.

The migration records of international students bring these patterns into sharp relief. Over half of the 4.8 million international students in 2016 were enrolled in educational programmes in just six countries: The United States of America; the United Kingdom; Australia; France; Germany and the Russian Federation (UNESCO, 2018). All of these receiving countries feature in the top echelons of the contemporary global market. The profile of sending countries, too, betray the western-influenced economic undertow of international student mobility. China, India, Germany, South Korea, Nigeria, France and Saudi Arabia feature prominently 
both as points of student departure and as dominant and emerging global economies (UNESCO, 2018).

Language binds with economy in determining migrant's destinations. This is most true of student migrants, who increasingly seek out educational experiences in English-speaking countries and English medium of instruction institutions (CANAGARAJAH, 1999). As expressed in the papers that follow, such experiences leave indelible marks on their actors, forging new identities both for those who leave as much as for those who stay at home. Commenting on her migration from Brazil to the States, Betty, a research participant in Christine Nicolaides' article (in the present volume) puts it like this:

"I was one person... I arrived as someone and I'll leave as some else, completely different..."

Betty's testimony is ambiguous in tone, haunting in finality. Migrant realities abrade migrant expectations. Languages meet and fall into fraudulent hierarchies. And the combined result is a life-long, multigenerational, search for belonging (O'BRIEN, 2017).

Repeatedly, the classroom enlarges to capture and respond to this complex web of intersecting experiences and expectations. Language teachers, in particular, must face the consequences that their students are bound to encounter in a globalized, multilingual world, while also attending to the traditions that characterize their places of origin. While daunting, educators have responded heroically to this challenge, developing an infrastructure of inquiry and practice that refuses to bend to the homogenizing forces of the global economy. Language ideologies (BLOMMAERT, 2006, LEEMAN et al, 2011) that have historically excluded minority language speakers are increasingly recognized and critiqued as symptomatic of a colonialist hangover. In turn, systemic language attitudes are tackled in classrooms through inclusive approaches that valorize concepts such as global Englishes (ROSE AND HALLOWAY, 2014; MATIAS SILVA, this volume), translanguaging and negotiated academic literacies (LILLIS, 2017, 2013; CARNEIRO, this volume). Threatened languages are being safeguarded by increasingly politicized educators and linguists, armed with the will to preserve their languages as well as newly-amassed, interdisciplinary-sourced knowledge to ensure its perseverance into the next generation (WYN SIENCYN, 2019). And, most hopefully, increased human contact enables us to reach across national divides and glean from one another's linguistic and educational repositories in ways that challenge modernist linguistic ideologies. 


\section{DETERRITORIALISED LINGUISTIC FLOWS}

Whereas population movements are at the centre of transnationalism as a concept, these are increasingly being situated within, and in contrast to, flows that are independent of territorial attachments and bounded communities. The movement of people is, indeed, outpaced by the massive, and massively unequal, flows of communication, technology, capital and culture (APPADURAI, 1996). Appadurai's (1996) notion of a global mediascape is particularly powerful within this perspective, and, perhaps, most tightly linked to the global rise of the English language. For countries such as Brazil, with small migration flows, it is through this mediascape that global cultural and linguistic flows gain a symbolic foothold, boosted by the economic power of the United States. One product of such flows is the prestige of the English language - particularly in forms identified with the USA and with the privilege of international travel - and reflected in the proliferation of commercial language courses and bilingual schools across much of the global south.

The notion of global flows downplays some of the local and regional dynamics that also contribute to transnationalism. This is evident in Border tensions between Venezuela and neighbouring Latin American nations, that play into electoral politics and nationalism, even as they are also expressions of the broader subordination of the region to US foreign interests. For example, Brazilian Vice President Hamilton Mourão, a nationalist army general, is able to pose as a regional peace-broker in broadcasts in which he speaks Spanish; while interviews in which he uses English are used to reassure the international press as to his own governments' democratic credentials. Morão's multilingual performances convey an image of cosmopolitanism for national, regional and global consumption that provides cover for, and at times contradicts, government discourses conveyed, and reported, exclusively in Portuguese. Further, while English appears to have an irresistible centripetal pull, other languages remain, or even gain, status within specific local and regional settings. Brazilian Portuguese has gained space relative to the European variety, and its standards are formalized in a globally-applied testing regime known as CELPE-Bras. South-south mobility, as well as specific institutions devoted to contacts within Latin America (UNILA) and with Africa (UNILAB) are examples (see Carneiro, this volume, for a discussion such movements).

The linguistic dynamics of the global south, rather than being made up of mere repositories of global flows, also register local productive practices (PENNYCOOK, 2010) and the traces of earlier phases of colonialism, including the enslavement of African peoples. It is the languages of formerly enslaved peoples that now become a central part of new semiotic repertoires in the global hip-hop 
movement, in the form of African American Vernacular English and Carribean Creoles. These find resonance and are remixed in marginalized communities that are also the products of histories of slavery, such as Brazilian favelas (WINDLE \& BRAVO, this volume). The transnationalism of language is, therefore, not merely the product of technological innovations or affordances, but intimately linked to long-term historical patterns in economic exploitation, often structured by extreme violence. The metaphor of flows, and similar paradigms such as superdiversity (VERTOVEC, 2007), indeed have limits when extending analysis to violence either in state repression or in strategies of resistance. The state monopoly on legitimate violence, and its contestation, is, for example, in the Brazilian setting, a central dimension of social and linguistic relations in favelas (SILVA, 2016), but largely beyond the scope of European and North American theoretical paradigms.

The present special issue, therefore, presents examples of small and middlescale theory construction that attend to the linguistic ideologies of speakers, and break down the modernist conceptions of speaking subject and language as autonomous and unified (MUITA-LOPES, 2014).

\section{ARTICLES: SUMMARIES AND COMMENTARY}

The articles making up this special edition are broadly grouped into two sections - the first focusing on the effects of population movements and the second focusing on deterritorialised linguistic movements.

Katherine Morales' paper begins this critical journey of transnationalism by raising its limitations as a conceptual framework for studies of Puerto Rican diasporic experience. The veracity of 'nation', Morales argues, becomes undone in such spaces, as political incorporation is undermined by cultural tradition. By consequence, Morales' ethnographically-observed participant Miguel, a17 year old attending an elite Puerto Rican high school, uses a system of socioindexicality that position him strategically between Puerto Rico and the mainland U.S., and that works to collapse the distinction between the two. Methodologically useful in mapping metapragmatics on to socioindexicality, the paper also raises important, perhaps underexplored, questions around perpetuated hierarchies of language prestige, and the role that private school education plays in releasing its participants from the systems of linguistic prejudice and marginalization that change the course of so many others.

Spatially remaining in the Caribbean, the social dimensions of academic conventions are the focus of Carneiro's contribution, in which he addresses 
what has been referred to as "the institutional practice of mystery" (Lillis, 1999) in relation to the reception of Haitian students in Brazilian universities. These mysteries involve unstated expectations and "hidden features" (Windle, RBLA) of academic literacies, including how texts circulate and construct scholarly identities. Carneiro's work, importantly, draws attention not merely to the difficulties encountered by Haitian students, but to the institutional blindness of higher education when faced with a group identified exclusively with poverty and outside of racially acceptable (white) student identities. Drawing on the notions of language ideology and metapragmatics, he shows how they shape the learning of geopolitically marginalized students of Portuguese, and presents pathways for developing a more productive and empowering stance in their academic writing.

Institutional blindness thematically reemerges in Jessica Garska and Sarah O'Brien's Irish-based study, the third paper in this issue. Drawing on insights gleaned from international students studying in an English medium of Instruction university, the authors argue for the necessity of adopting an academic literacies approach to overcome despotic language and cultural hierarchies in the Irish academy. Based on interviews and writing samples from international students enrolled in an English for Academic Purposes programme, the authors draw out the tension between, on one hand, students' subtle biases toward inner-circle English language norms and, on the other, their own frustrations with conforming to normative academic principles that they see as one sided and exclusivist.

This question of inclusivity and sentiment of resistance is maintained by the Christine Nicolaides' "Reframing identities in the move: a tale of empowerment, agency and autonomy." The article sees its author engage in interplays between language and identity, questioning the extent to which foreign language learning experiences and second language acquisition give rise to alternate notions of self and home. Based on interviews with two female Brazilians, one an alumnus of Science Without Borders ( $\mathrm{SwB}$ ), the other an au pair, Nicolaides draws out thematic similarities and differences in both women's journeys to Australia and the States respectively. She holds up for examination within this study the concept of communities of practice, suggesting its crystallization as a sort of mental and linguistic orbit for both women. Desired and desirable, the English-speaking communities of practice that her participants seek out inevitably challenge their right to fully belong within their terrain. These challenges are shot through with embedded ideologies around race, class and language prestige, within each of which Nicolaides' participants are cast as deficit, to varying degrees. They are influenced too, by the pre-existing experiences and aspirations that international students 
bring with them to their new worlds. JULIA, who spent her SwB term in Australia after her first choice of Portugal fell through, had little prior investment in joining an English-speaking community of practice. By consequence, she was accepting of the linguistic and cultural barriers that hampered her participation in the surrounding English- speaking community, rationalizing her liminality as the valid position of a beginner English language learner. Betty, on the other hand, held high expectations of her ability and right to participate fully in the States: an expectation that was soon shattered by the insider/outsider paradigm that she encountered within her host family. Within this context of marginalization, Brazil becomes reimagined as a safe and welcoming space. And so, a cycle of imagined communities begins anew.

From migrant narratives of Brazil we journey to transnational migrant narratives recorded in Mexico. Alejandra Nuñez's article navigates the pools of knowledge, values, beliefs, practices and skills that manifest through transnational movements across the U.S/ Mexico border, and that consequently reframe returning migrants' experiences. The question of the returnee migrant and their perpetuated psychological suspension between two worlds is often neglected by migration literature. Nuñez' article, driven by Labovian methodology and framed by a conceptualization of social remittances, provides a strong foundation through which further studies of the returning migrant experience may be more systematically explored.

Leading off a thematic navigation of transnationalism precipitated by digital exchange is Joel Windle and Barbara Bravo's article, "Plurilingual social networks and the creation of hybrid cultural spaces." Encompassing the ambit of deterritorialised linguistic movements, the authors explore the possibilities of digital ethnography in revealing the plurilingual practices of Brazilian youths drawn from marginal social backgrounds. Focusing on (mostly) English language comments posted to a facebook page devoted to Back American and hip-hop culture, the article provides fascinating insight into the means by which translanguaging practices pace and track developments of identity. Importantly, Windle and Bravo's article masterfully casts much needed light on subaltern identity construction and meaning making on the social margins. While specific to the Brazilian context the paper's findings fluidly modulate from the particular to the general, providing food for thought on the possibilities of extending this frame of inquiry to comparative subaltern communities.

Grounding her work in the literature on language ideologies, Silvia Matias Silva investigates the complex politics of English as a Lingua Franca, a concept which seeks to decentre and pluralise the hegemonic linguistic entity that enters classrooms. Using an original experiment in a Brazilian public school, Matias Silva 
shows that exposing students to multiple varieties of English is insufficient to challenge monolithic linguistic ideologies, and that American accents are preferred to Indian accents in teaching materials presented to Brazilian learners of English. The positive associations of American accents as "original" and "beautiful" suggest to Matias Silva the need for critical intercultural education (Byram, 2008), in which the teacher plays a key role in expanding students' concepts of both language and cultural diversity. It is noteworthy that students of the study, located in a disadvantaged urban periphery, in addition to rejecting Englishes from the global south, are themselves marginalised by the linguistic, racial and social ideologies embodied in standard Brazilian Portuguese, their "native" language.

Returning to the domain of academic writing in third-level education, Suzanne Mizen's article, "Transnational imaginaries of emerging identities in English teacher education in a period of accommodation to social change in Brazilian Higher Education" points out that transnational identities can emerge without any prerequisite movement across borders. Technology, Mizen suggests, plays a potent role in opening up alternate national narratives and in shaping the mindsets of those who stay at home, or who migrate internally. Such democratic and expanded views of translocal performances and agency are vital in fully meeting the boundaries and measuring the dimension of transnationalism.

In a fascinating interview framed by the shadow of neoliberalism, Brian Morgan carves out from a complex knot of theoretical arguments and discursive positions, one critical question: how do we, as language practitioners, act under the regimes into which we have been doomed? Smoothly, Morgan scans an eye down along the global critical landscape, noting its deep contours in Brazil in comparison to its plains-like quality in North America. But observation of each other's different ideological stances is no longer enough. To arrive at a solution, Morgan asks for the coupling of theory and practice that make buoyant the peculiar, voracious and ever evolving art of language teaching. Nudging his interviewee beyond the boundaries of language and literacies, Daniel Farraz opens out the conversation to grapple with national treatments of sexuality and gender. In so doing, he invites a subtle but resonant message to tremble through the corridor of this journal. Beware, it warns, of the processes that replace criticism with conformity.

\section{REFERENCES}

APPADURAI, A. Modernity at large: Cultural dimensions of globalization. University of Minneapolis: Minnesota Press, 1996. 
BLOMMAERT, J. (2010). The Sociolinguistics of Globalization. Cambridge, UK: Cambridge University Press.

BLOMMAERT, J. (2006) Language ideology. IN: T. Todorov (Ed.) Handbook of Language and Linguistics. Vol. 6, p.510-523. Elsevier.

BRIGGS, L., MCCORMICK, G., \& WAY, J. T. (2008). Transnationalism: A category of analysis. American Quarterly, 60(3), p. 625-648.

BYRAM, M. (2008). From Foreign Language Education to education for Intercultural Citizenship: essays and reflections. Clevedon, Bufalo, Toronto: Multilingual Matters.

CARDARELLI, R. (2018). Solving the Education Crisis of Displaced Children: A most important goal for education diplomacy. Childhood Education, Vol. 94, 2018 - Issue 3: A Special Issue on Education Diplomacy, p. 61-66.

CANAGARAJAH, S. (1999). Resisting linguistic imperialism in English teaching. Oxford: Oxford University Press

CONNELL, R. (2007). Southern theory: The global dynamics of knowledge in social science. Cambridge: Polity.

INTERNATIONAL ORGANIZATION FOR MIGRATION (2018). Global migration indicators. Berlin: Global Migration Data Analysis Centre.

JACQUEMET, M. (2005). Transidiomatic practices: Language and power in the age of globalization. Language \& Communication, 25(3), p. 257-277.

KACHRU, B B. (1985). Standards, codification and sociolinguistic realism: the English language in the outer circle. In: QUIRK, Randolph; WIDDOWSON, H. G. (Orgs.). English in the World: Teaching and Learning the Language and Literatures. Cambridge: Cambridge University Press, p. 11-33.

LEEMAN, J., RABIN, L., \& ROMÁN-MENDOZA, E. (2011). Identity and activism in heritage language education. The Modern Language Journal, 95(4), p. 481-495.

LILLIS, T. (2017). Resistir regímenes de evaluación en el estudio del escribir: hacia un imaginario enriquecido. Signo y pensamiento, 36(71), p. 66-81.

LILLIS, T. (2013) The Sociolinguistics of Writing. Edinburgh: Edinburgh University Press. 
LILLIS, T. (1999). Whose "Common Sense"? Essayist literacy and the institutional practice of mystery. In: Jones, C.; Turner, J.; Street, B. (Orgs.). Students writing in the university: cultural and epistemological issues. Amsterdam: John Benjamins, p. 127-148.

MOITA-LOPES, L. P. (2014). Global Portuguese: linguistic ideologies in late modernity. New York: Routledge.

O’BRIEN, S. (2017). Linguistic Diasporas, Narrative and Performance. London: Palgrave.

PENNYCOOK, A. (2010). Rethinking origins and localization in global Englishes. In: SAXENA, M.; OMONIYI, T. (Orgs.) Contending with globalization in World Englishes. UK: Multilingual Matters, p. 196-233.

ROSE, H and GALLOWAY, N. (2019). Global Englishes for Language Teaching. Cambridge: Cambridge University Press.

SCHEFFNER HAMMER, C., DUNN DAVISON, M., LAWRENCE, F. and MICCIO, A (2009). The effect of maternal language on bilingual children's Vocabulary and emergent literacy development during Head Start and Kindergarten. Scientific Studies of Reading 13, no. 2, p. 99-121.

SILVA, Daniel Nascimento. (2016). Comunicando a -pacificação- e a violência. Signotica (UFG), v. 28, p. 405-431.

UNITED NATIONS DEPARTMENT FOR ECONOMIC AND SOCIAL AFFAIRS. (2017). International Migration Report: Highlights. New York: United Nations

VERVOTEC, S. (2007). Super-diversity and its implications. Ethnic and racial studies, 30(6), p. 1024-1054.

WINDLE, J. A.; NOGUEIRA, M. A. (2015). The role of internationalisation in the schooling of Brazilian elites: distinctions between two class fractions. British Journal of Sociology of Education, v. 36, n. 1, p. 174-192.

WYN SIENCYN, S. (2019). Early years' provision for young children in Wales: history, challenges, and the Welsh language" Teanga Special Issue: Multilingualism in the Early Childhood Years, 10, 10, 2019

Recebido: 20/03/2019

Aceito: 26/03/2019

Publicado: 29/03/2019 